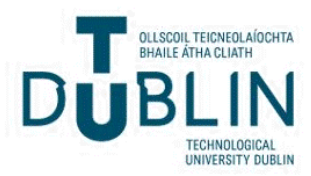

Technological University Dublin

ARROW@TU Dublin

$2012-2$

\section{The Dynamic Role of Entrepreneurs in Destination Development}

Theresa Ryan

Technological University Dublin, theresa.ryan@tudublin.ie

Ziene Mottiar

Technological University Dublin, ziene.mottiar@tudublin.ie

Bernadette Quinn

Technological University Dublin, bernadette.quinn@tudublin.ie

Follow this and additional works at: https://arrow.tudublin.ie/tfschhmtart

Part of the Tourism and Travel Commons

\section{Recommended Citation}

Ryan, T., Mottiar, Z., Quinn, B.: The Dynamic Role of Entrepreneurs in Destination Development. The Journal of Tourism Plannning \& Development. 2012. doi:10.1080/21568316.2011.630747

This Article is brought to you for free and open access by the School of Tourism \& Hospitality Management at ARROW@TU Dublin. It has been accepted for inclusion in Articles by an authorized administrator of ARROW@TU Dublin. For more information, please contact arrow.admin@tudublin.ie, aisling.coyne@tudublin.ie, gerard.connolly@tudublin.ie.

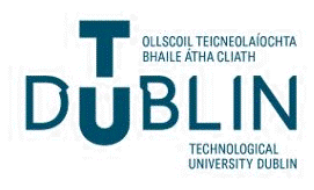




\section{The Dynamic Role of Entrepreneurs in Destination Development}

\section{Introduction}

One of the most cited works in the tourism literature is Butler's (1980) contribution to the understanding of the development of destinations. Concern with how and why destinations develop is still as important today, and yet arguably our understanding regarding this matter has not advanced significantly over the last 30 years. In particular analysis regarding the role of entrepreneurs in this development is sparse, and there has been an underestimation of the historically important role that individuals can play in determining the current position of a destination. This paper investigates the role that entrepreneurs play in the development of tourism destinations using a case study of one of Ireland's leading destinations, Killarney, Co. Kerry. The case is used to argue that entrepreneurs act as a key 'tourism influentials' that are highly influential at given points in time, inherently dynamic and capable of have long lasting effects on shaping the fortunes of a destination over time.

Theoretically, the paper draws on the literature on models of destination development (e.g. Christaller, 1963, Miossec, 1976, Butler, 1980, Gormsen, 1981, Lundgren, 1982, Keller, 1987, Lewis, 1998 and Ritchie \& Crouch, 2003). While this literature has recognised the influential role of entrepreneurs in the destination development process, it is argued that in general, these models have underplayed the influence that local entrepreneurs play in tourism development. In particular, Butler's (1980) much cited Tourism Area Life Cycle model only hints at the role of local entrepreneurs in the early stages of development (Shaw \& Williams, 1998). Overall these models fail to explore and examine the impact of entrepreneurs in any depth. This omission is noted by Hovinen (2002) who acknowledges that the importance of entrepreneurial activities as potential triggers for change is not addressed by the models. Similarly, Coles (2006) explains that the models have been critiqued for their tendency to treat the human as a passive entity that receives stimuli, which it dutifully processes. He argues the need to 'explore the role of the individual human as an active subject with conscious designs' and 'to 
expose the logic which binds these designs together' (ibid: 50). The contention of this paper is that to comprehensively understand tourism development it is necessary to investigate its complexity and in particular, to understand the dynamic and historical role of entrepreneurs in its development. However, while the subject of entrepreneurship remains an underexplored topic (Koh, 2002), there are indications that more attention is now being paid to the topic (Ritchie \& Crouch, 2003) and there is evidence that this area of research is beginning to gather some momentum $(\mathrm{Li}, 2008)$. This paper seeks to further redress this imbalance by investigating how entrepreneurs effect and maintain tourism development in localised places over time. It seeks to understand, for example, how entrepreneurs are implicated in stimulating specific developments, advancing vital infrastructure, promoting particular approaches to development and cultivating particular entrepreneurial cultures in local tourism contexts. It is particularly concerned with evaluating the extensive and long-lasting influence of entrepreneurs on tourism development in localities.

\section{Entrepreneurs and tourism development}

Koh \& Hatten (2002: 21) clearly recognise the importance of entrepreneurs in tourism development claiming that 'a community's quantity and quality of supply of entrepreneurs significantly determines the magnitude and form of its touristscape because the tourism entrepreneur is the persona causa of tourism development'. They claim that 'it is only when tourism entrepreneurs are present, do a community's climate, landforms, flora and fauna, historic vestiges, and ethno-cultural enclaves become tourism resources that may be transformed into tourist attractions' (Koh \& Hatten, 2002:27). Without the influence of entrepreneurs it is doubtful that a tourism industry would evolve, even in areas that are favourably endowed with resources (Koh and Hatten, 2002). Russell \& Faulkner (1999, 2004) and McKercher (1999) similarly clarify the integral part that entrepreneurs play in developing tourist destinations, recognising them as 'rogues or chaos makers' (McKercher, 1999:432). Despite this recognition that the 'innovation, flair and vision of entrepreneurs ... shaped modern tourism' 
(Russell, 2006: 105), and the fact that 'the hospitality and tourism industry has been a fertile field for entrepreneurial business' ( $\mathrm{Li}, 2008$ : 1013), little has been done to provide a comprehensive understanding of the way and extent to which entrepreneurs influence tourism development. Models of tourism development, for example, in general pay only scant attention to entrepreneurs. Early models such as Christaller's (1963) identify their role in developing infrastructure while other such as Miossec's (1976) and Lundgren's (1982) are largely concerned with the role of access and transport, geographic location and physical attributes. The much cited model by Butler (1980), the Tourism Area Life Cycle (TALC), identifies the role of local entrepreneurs in developing tourist services, facilities and promotional activities at the involvement and development stages of tourism development, but sees their role decreasing in later stages. According to Shaw \& Williams (1998: 237), their role is only 'touched upon' by the model and Butler does not elaborate on entrepreneurial activity, in fact they claim, much of Butler's discussion was 'vague and implicitly relied on unresearched ideas'. Tinsley \& Lynch (2001) view the TALC system as static, without a dynamic element, which fails to consider important intangible elements such as networks and their contribution to development. These criticisms can be applied to other models such as Gormsen's (1981) and Keller's (1987) which primarily stress the importance of local control and benefits for tourism communities as fundamental to development. Two models that provide some insight into the way in which local entrepreneurs influence development are Lewis's (1998) and Ritchie \& Crouch's (2003). Lewis in particular identifies the role of local entrepreneurs as triggers of change, highlighting the dynamic power relations that can underpin tourism development. Ritchie \& Crouch provide a more dynamic understanding of the part that entrepreneurs and small businesses play in creating competitive advantage explaining that they are '...of fundamental importance to the development of tourism as an industry' (Ritchie \& Crouch, 2003: 140). Small firms, they contend, contribute to destination development and competitiveness through their strategy, structure and rivalry, in particular, through inter-firm competition and co-operation. According to Ritchie and Crouch the competition generated between small firms in a destination 'creates an environment for excellence', 
while the interdependence between firms encourages inter-firm co-operation (Ritchie and Crouch, 2003: 141). However, while the models in general make some reference to the influence of entrepreneurs and small businesses they largely fail to recognise and explore their role as crucial agents of development. Consequently there remains a need to 'explore the role of the individual human as an active subject with conscious design' and to 'expose the logic which binds these designs together' (Cole, 2006: 50).

In the broader tourism literature the pervasive influence of entrepreneurs is more apparent. Authors such as Shapero (1981) and Pearce (1995) suggest that entrepreneurship provides communities with the diversity and dynamism that assures continuous development and its influence may extend beyond individual development projects to stimulate others to undertake development. Britton (1991) clarifies how the building of just one hotel in an area can trigger further development because it provides a base from which further construction can proceed and signals a confidence in the location. Hall (2004) similarly acknowledges that innovation in New Zealand has occurred primarily because of champions and individual innovators who have been able to generate local interest and involvement. Mottiar and Tucker (2007) acknowledge a growing number of significant studies which show how small tourism firms and entrepreneurs can make a significant impact on the development and operation of a destination. They refer to the work of Scott and Laws (2004) who explore the role of small firms in the evolution of Hervey Bay, Australia as a whale watching destination. They also note Johns \& Mattsson's (2005) research on the impact that a single entrepreneur had on destination development in Hay-on-Wye. Similarly, Keen (2004) in his study of tourism in New Zealand, claims that social or community entrepreneurs were the main facilitators of development. Hall (2005) claims that in regional and rural areas of many countries small businesses and entrepreneurs are the foundation of the tourism product, delivering the tourism reality, quite often in the form of niche products based on the resources available to them. They provide the platform that makes a region 
accessible and attractive (Hall et al., 2007). This idea of entrepreneurs influencing development beyond their own individual contribution may be fundamental to understanding the extent of their influence on tourism development, yet this has not been explored to any great extent within the tourism literature.

In this context of destination development and how it is influenced by the actions of small firms and entrepreneurs, 'a further body of knowledge highlights their economic significance through the importance of collaboration and networks' (Thomas et. al. 2011: 969). Johns and Mattson (2005: 606) for example, in their study of two destinations clearly identify how the entrepreneurial objectives of two businessmen were achieved through the use of formal and informal networks at the destination. Hall (2004) draws attention to the impact of networks and cluster relationships between firms which, he explains, are the primary 'drivers' of a region’s economy. Tinsley \& Lynch (2001) explore the networking practices of small tourism businesses in a rural destination in Scotland and identify the role that co-operation between these businesses played in destination development. Michael's (2007) focus on the influence of micro-clusters on tourism development similarly identifies the role that local operators play in developing co-operative and complementary interactions that enable them to exploit synergies creating their own comparative advantages. Michael refers to the geographic concentration of a small number of firms in a cohesive environment, "where the complementary interaction between these firms contributed to an enhanced level of local specialisation' (2007: 2). This, he claims, shifts the focus of analysis in economic development to individual localities and towns, villages and the people who live in them. Mottiar and Ryan (2007) take an industrial district approach identifying communities of firms and entrepreneurs as critical sources of successful destination development. This idea of small firms as 'driver's' of development is also addressed by Tinsley \& Lynch (2007: 162) who explain that 'much of the generic tourism literature suffers from a lack of understanding of small businesses' and address this omission by highlighting that community embedded business 
networks can demonstrate successful control over the destination's tourism development (Tinsley \& Lynch, 2007: 175). 'The patterns that appear to be evolving from a range of research analyses in these fields seem to suggest that a core of 'entrepreneurial' key persons are crucial for tourism and community development to take place' (see for example, Brulin \& Nilson, 1997; Frisk, 2000, 2003; Gibson et. al. 2005; Johnannisson, 1988, 1997; Karlsson \& Lönnbring, 2003; Philips, 1988; cited in Gibson \& Lynch, 2007: 111). Outside of the tourism literature there has been extensive recognition of the importance of entrepreneurs as economic change agents and as key factors in creating competitive advantage for localities. It is clear therefore that recognition of the role of entrepreneurs and in particular, of communities of entrepreneurs and small firms on tourism development, has gained momentum in the literature. Despite this there remains considerable scope for exploring tourism entrepreneurs and the way in which they actively interact with and shape their local environments. This paper adds to the tourism literature by identifying the dynamic role of entrepreneurs within the context of Killarney an established tourism area in Ireland. In order to achieve this, the research takes a historical perspective, looking back to the beginnings of the tourism industry in Killarney in the 1700s. The objective is to look historically and to identify the way in which entrepreneurs and small business operators have acted as key 'tourism influentials' in developing the industry that exists in Killarney today.

\section{Methodology}

This research is part of a larger project that examines the factors underpinning tourism development. Using a case study approach it examines entrepreneurial activity in Killarney, Co. Kerry, a developed tourism area in Ireland. The use of case study methodology allowed the research to capture the dynamics of tourism development in its context, providing a flexible framework that favoured the use of both quantitative and qualitative data. The case area was chosen using purposive sampling; Killarney was chosen on the basis of its classification in Ireland's National Tourism Authority's 
(Fáilte Ireland) Tourism Development Plan 1994-1999, as a major tourism centre. Killarney is the only rural town to achieve this classification all other major tourism centres are cities. In addition, there is a well established acknowledgement both nationally and internationally, among suppliers, consumers and tourism commentators more generally, that Killarney is a leading tourism destination and this was a key reason for choosing it.

The research is underpinned by a pragmatic approach that involves mixed-method research and involved the use of: archival research, surveys, interviews, observations and field notes. An analysis of archived sources of information provided extensive background knowledge of the areas and the entrepreneurs being studied this included: official and government statistics, historical documents, industry reports, administrative records and documents etc. The primary research was undertaken in 2005 and began with a survey in the form of a questionnaire which was administered to local tourism suppliers by the researcher. Eighty-one firms were surveyed, representing approximately one third of tourism firms in the area. Each survey took between 20 minutes and 1 hour to administer and while random sampling was used, care was taken to ensure that different sub-sectors of the market was represented. The survey supported the research by guiding the researcher in determining potential subjects for interview as well as highlighting key themes. In addition, thirteen in-depth interviews were undertaken in Killarney. The use of snowball sampling as an approach that supports the identification of information rich key informants was used to identify relevant individuals (Patton, 2002). The interviews were structured as 'guided conversations' in which the researcher could steer the respondents around specific topic areas and provided a high level of contextual understanding. Reflections and introspection were also important parts of the research and observations and field notes taken during the research period informed the research and formed an integral part in the interpretation of the findings. These multiple sources of information were used in a converging fashion enabling the researcher to obtain a better, more substantive picture of the influence of entrepreneurs on tourism development. 


\section{Killarney, Co. Kerry: an established tourism area in Ireland.}

Killarney town is situated in the county of Kerry, in the South West of Ireland. Although traditionally a market town, Killarney owes its growth primarily to the successful development of tourism. It is recognised both nationally and internationally as one of Ireland's premier tourist destinations and, while no official statistics exist, unofficial estimates suggest that up to 1.5 million people visit the town each year (RPS Cairns, 1999). Tourism is a major component of the local economy, providing both direct and indirect employment (ibid). Killarney is removed from centres of high population density, the nearest major city Cork is $86 \mathrm{kms}$ in distance, while Dublin, the capital of Ireland, is $345 \mathrm{kms}$. It is the home of Ireland's first national park which covers an area of approximately 10,236 hectares of mountain, moorland, woodland, waterways, parks and gardens (Killarney national Park, 2008). The town of Killarney nestles at the foot of Ireland's highest mountain range; the MacGillycuddy Reeks. Behind the town are the three famous Lakes of Killarney; the Upper Lake, Muckross Lake (the Middle Lake) and Lough Leane (the Lower Lake) which occupy a broad valley stretching south between the mountains. The area is most notable for these world-famous lakes, combined with its rugged beauty of valleys, mountains and an extraordinary wealth of trees and rare flowering plants (Flynn, 1993). The scenic splendours of the area are without doubt its principal tourist attraction (Larner, 2005) providing it with formidable advantages as a tourist centre (Barrington, 1976), however the natural landscape alone does not account for the industry that has developed. Tourism development can be largely attributed to the influence and efforts of local entrepreneurs. From as early as the 1700 s, long before Ireland as a nation had recognised the importance of tourism, local individuals in Killarney had recognised the opportunity that the surrounding landscape afforded for attracting visitors to the area. Throughout its history, tourism development has been underpinned by the vision and commitment of entrepreneurs whose influence has extended beyond their individual development projects to stimulate others to become involved in the industry and in many cases their impact has lasted long after the work of the original entrepreneur. 
An overview of these key entrepreneurs and their role as 'tourism influentials' explains the way in which they influenced development and the extent of this influence which has had a long-lasting and far-reaching impact on what has become Killarney's most important industry.

\section{Entrepreneurial influence on tourism development in Killarney}

Historical records indicate that the beginning of Killarney's entrepreneurial dynamism can be traced back to the 1700s to the time of Thomas Browne, the Fourth Viscount of Kenmare. Browne was landlord of the Kenmare estate between 1747 and 1795 and was a hugely influential character in the development of tourism in Killarney. Reflecting the findings of Koh \& Hatten (2002), the archival research indicates that Browne was responsible for initiating development and his entrepreneurial ideas can be seen to have transformed Killarney into a tourism destination in the first instance. Barrington (1976) explains how Browne influenced and actively encouraged the establishment of inns, the provision of boating facilities and guides while also using his influence to encourage the local gentry to apply for a turnpike road to improve access to Killarney (O'Hare, 2005). As one of the largest landowning families in the area, Browne's reasons for this development may not have been for altruistic purposes and may have been driven by the need to cover the ever increasing costs of maintaining his estate (Corr, 1994), however its impact was to have profound effects on the local area over many years. The crucial role that Browne played in initiating tourism was strongly supported by interview respondents as many were quick to discuss his influence, claiming that 'you have to consider the work of Thomas Browne, he was a huge influence, he started everything' another explained that Killarney 'became a tourist resort because of Thomas ... who had a vision for tourism', while another contended that Browne 'was a key influence and this influence was passed down over the years allowing people to see an opportunity to develop the industry'. Similarly, $25 \%$ of survey respondents acknowledged the importance of his role in tourism development in Killarney, but more significantly many others spoke of the role that he played in 'starting tourism in Killarney' speaking 
of how critical his vision was to its development. One survey respondent explained that 'the influence of Thomas [Browne] is as important today as it was then'.

The archival research shows that through his actions in developing tourism infrastructure and services he facilitated visitors to the town and more importantly demonstrated the opportunity that existed for tourism in Killarney. He provided land to the Great Southern Railway for the building of the first railway hotel in Ireland, the Great Southern Hotel, which opened in 1854 (Furlong, 2009), a factor that was acknowledged by interview respondents as 'a key factor' as it 'brought important visitors to the area'. Of great significance was Browne's encouragement of tenants involvement in the industry, 'a most considerate and enlightened landlord at a period when Irish landlords and their agents were a byword for harshness' (MacLysaght, 1970: 141). Estate records show how he granted his tenants a lease forever for a trivial rent, and encouraged them to improve their landholdings in order to make the town more attractive to visitors (The Kenmare Papers, 1750-1850). He helped develop a keen awareness of the potential for tourism and a desire to encourage and cater for visitors developed in the town (Smith, 1756). He was a progressive landlord and he stimulated the beginning of the industry and an entrepreneurial dynamism that exists right up to the present day. His vision for tourism and efforts to highlight the opportunities afforded by the natural beauty of the area helped initiate a sense of place and a self reliance that continues to form part of the fabric of Killarney's tourism industry. As explained by one respondent 'Thomas ... had a great vision for the town and encouraged tenants to develop their holdings and to provide services to tourists such as guided tours and boating trips, because of all of this, tourism is ingrained in Killarney people' it is according to other respondents 'a way of life' and there is 'oneness in the town' with regard to tourism. One respondent explained that 'the local Aristocracy built up tourism and the tradition is now ingrained in the area'. After his death in 1795 , he left behind a legacy of development in Killarney but more significantly, he left the beginning of what was to become Killarney's most important industry. At a time of extreme poverty in Ireland he encouraged a self-reliance and determination to succeed in the town that continues to exist today, a factor that is still recognised by locals as one respondent explained, 'local businesses get 
out there and do it themselves, this is their culture and tradition'. The archival research shows that Browne was a key instigator of early tourism development. His influence was of paramount importance and transcended the tangible elements of tourism development to include the beginnings of a culture of tourism. This culture remains integral to the industry today and is evident in the way that tourism has become part of the fabric of Killarney as the town 'draws its life from catering to tourists' (Atkinson, 1956:52). It is according to interview and survey respondents, apparent in the fact that tourism in Killarney is 'just what people do' it is 'a way of life' as 'people have a common history and belief in tourism', 'it is their culture and tradition'. Hall \& Hall (1853) recognised this culture during their visit to Killarney in the 1800 s when they declared that every 'child, boy or girl, from the time it is able to crawl over the door-step, seems to have a strong natural instinct to become a guide'.

Browne's influence and contacts stretched far beyond Killarney and was to continue through his family, even after his death in 1795. Evidence from archival sources indicates that through their many contacts his family were instrumental in attracting royalty to Killarney, including a visit by Prince Edward in 1848. However, the real extent of the family's contacts and influence is evident when they were principal hosts to Queen Victoria during her visit in 1861 (Horgan, 1988). Archival material indicates that the family were well aware of the huge financial spin-offs that would accrue to Killarney because of the visit. The extensive publicity was invaluable and went a long way towards establishing Killarney as a Victorian tourist resort, helping put it on a par with resorts such as Lake Windermere in the English Lake District (Horgan, 2005: 131). The importance of this visit for tourism in Killarney is still recognised by locals as interview respondents were quick to point out that 'the Kenmare family were key to Queen Victoria's visit' and this 'put Killarney on the map'. The story of Killarney tourism began with Browne, and has continued through the involvement and vision of other entrepreneurs through the years. 
Maurice O'Donoghue, (1938-2001) is another local entrepreneur that has had an extensive influence on tourism development through developing the family's core business of accommodation and entertainment. This has not only meant the success of the family business but has also provided critical infrastructure and attractions for Killarney town. While there is no question but that the work of O'Donoghue was undertaken primarily for the benefit of the family businesses, there is no doubt but it also had an extensive influence on the area in general, as well as other businesses in the town. O'Donoghue was acknowledged by $47 \%$ of survey respondents as having contributed most to tourism development in Killarney. He was referred to as a 'champion for Killarney' by one prominent business person while another called him 'a modern day Thomas Viscount the Fourth'. One respondent explained that the opening of the Glen Eagles hotel by O'Donoghue in 1957, was 'a vital move in signalling a renewed confidence in the area after a period of relative inactivity due to the war of Independence, the Civil war, the Second World War and the political environment in Ireland at the time'. In addition, his continued development provided critical infrastructure and influenced the success of smaller operators in the area through the resulting increase in visitors as well as his policy of utilising the services of smaller businesses such as local tour operators and bicycle rental shops. One local business owner explained that 'most of our business comes from the Glen Eagles ... they are always running promotions and they use us so that means more business for us'. This was by no means a charitable undertaking as it allowed his businesses to offer a seamless product to their customers; while also creating important business for smaller businesses, allowing them to flourish. This tendency for O'Donoghue to concentrate on his core business (accommodation and entertainment) enabled other operators to successfully develop complimentary services which together provide a comprehensive tourism product. A representative of O’Donoghue's Glen Eagles Hotel explained that there are 'strong relationships with businesses going back over the years' and that it has always been the companies policy to 'support other businesses as much as possible' as 'this has always been part of what we do, we know that this benefits us and the whole area in the long run and that is critical'. 
O'Donoghue's extensive influence on tourism development included his involvement in developing domestic tourism in Killarney. One interview respondent explained that in the 1980s he teamed up with Iarnród Éireann (Irish Rail) and developed an initiative that included an all-in package of rail trip, entertainment and accommodation in Killarney. This, the respondent explained ' helped changed the perception in Killarney of the Irish domestic market and led the way for further development' and 'while his own hotel' undoubtedly benefited, 'the entire town ... enjoyed the spin-off from this activity' (Cork Examiner, 1979). O'Donoghue was also a very active member of the local community and his role in Killarney extended beyond his own business enterprises to include membership of, amongst other things, the board of Fáilte Ireland (the Irish tourist board). The degree to which this role impacted directly on Killarney tourism is difficult to quantify however, a position such as this would have helped keep Killarney to the forefront of Irish tourism and involved in policy making discussions. After his death in 2001 tributes were paid to O'Donoghue by the then Tourism Minister, Dr. James McDaid who acknowledged him as 'a dynamic figure in the growth and development of tourism in Killarney' while the Justice Minister John O'Donoghue referred to him as the 'King of Killarney'. O'Donoghue's influence continues through the work of his family, and in particular through his son Patrick who has completed many of his plans. O'Donoghue's son has been mayor of Killarney as well as a member of Killarney Urban District Council, the National Tourism Review group, and a director of Fáilte Ireland and Tourism Ireland, and has followed in his father's footsteps in terms of his involvement in the local community and tourism industry as well as the broader national tourism industry. The family continues to influence a great deal of tourism development in the town.

Tourism in Killarney has also been influenced by the long-term vision of a number of additional strong entrepreneurs many of whose involvement has been passed on over generations. In addition to the Browne and O'Donoghue family, families such as the Hilliards, the Treacy's, the O’Donoghue/Ring's, the Buckley's and the Randles amongst others, were acknowledged by survey and interview respondents as having all played a significant role in tourism development in Killarney. 
One respondent explained that 'there are a number of very strong local families for example, the O'Donoghues, O'Donoghue/Ring, the Treacys and the Randles are a few who have been involved for years'. One respondent explained that tourism in Killarney has been successful because of these entrepreneurs 'having had the foresight and bravery to help develop the product'. Many of them have become serial entrepreneurs with deep roots in the community and their continued development has instilled a confidence in the local industry and influenced the involvement of others. The industry, one respondent claimed, 'has been driven by the effort and investment' of these local entrepreneurs. Their vision for tourism, passed on, in many instances, over generations has created a dynamic environment that stimulates and enhances tourism development. As one respondent remarked; 'there is a very strong tradition of tourism in Killarney ... passed through generations - it's in the blood'. This tendency for entrepreneurs to pass on their businesses over generations can be seen across a range of businesses; jaunting car drivers, known locally as Jarvey's, spoke of grandfathers, fathers and uncles starting the business and passing it on to family members over generations while tour companies and hotel owners spoke of tracing their businesses back to the $1800 \mathrm{~s}$. As a result there is a familiarity among business owners that has influenced their willingness to co-operate for mutual benefit. From observations made during the research it is apparent that a shared history and involvement in tourism is of key importance to the way in which the industry has developed. As one respondent explained 'everyone is tourism focused and always has been right back to the beginning'. The town is characterised by a large number of locally owned businesses, $59 \%$ of businesses surveyed were owned by local Killarney people and a further $11 \%$ were from the surrounding area. Survey respondents $(83 \%)$ confirmed that this strong local involvement has underpinned the development of the industry. What is particularly apparent is a tendency for these local entrepreneurs to take a collective, long-term vision of tourism development this is reflected in one respondents comment that 'with family owned businesses the long-term view is looked at rather than the short-term economic rewards'. Their actions are, according to one respondent, underpinned by a 'common history and belief in tourism', and they have provided critical infrastructure and marketing support that has 
'developed their own businesses and supported the success of Killarney tourism'. Their tendency to develop through sticking to their core business provides an opportunity for other's to involve themselves in the provision of complimentary add-on services and products and ensures the success of individuals businesses and of Killarney tourism. Tourism is characterised in the area by the existence of many small businesses each providing essential components of the overall tourism product, this has created an interdependence between the businesses and as a result tourism firms have been able to survive and the local area able to thrive. The level of co-operation that exists is evident in for example the forming of marketing alliances, sectoral associations and management structures. Local entrepreneurs exert a strong influence on tourism through a history of involvement in local marketing and business organisations such as: Killarney Development Company, Killarney Chamber and Commerce, Killarney of the Welcomes, Killarney Tourism, Killarney Incentive and Conference Group. In addition, their active involvement in regional and national lobbying groups such as the IHF (Irish Hotel Federation) ensures that local businesses and the commercial interests of Killarney are represented in dealings with local government and national state agencies. This also provides an opportunity for members to network with each other as well as with members of other similar organisations at a regional and national level.

\section{Conclusions}

Butler's (1980) contention that local control on tourism decreases overtime is not evident in Killarney and his suggestion that local entrepreneurs may influence local tourism development only in the early stages of development is similarly unfounded. In Killarney right up to the present day and this extensive influence is seen to exist through all stages of development. The power of local entrepreneurs has helped to shape Killarney tourism and the industry is characterised by an entrepreneurial pervasiveness that has played a pivotal role in tourism development. Entrepreneurs have acted as triggers of change and development and have encouraged and facilitated the 
involvement and success of others in the industry. Their influence is not static but has continued to influence development long after the individual entrepreneur has ceased to exist. In the case of Thomas Browne, his legacy has been the initiation of the industry and a culture for tourism, and each entrepreneur has helped to sustain this culture over the years, what may have started in Killarney as one person's vision has become the collective vision of many. Local entrepreneurs can be seen to have acted as champions and individual innovators (Hall, 2004), providing critical infrastructure and marketing for the area but more importantly, supporting an environment where complementary businesses can flourish. Their approach to development has involved a collective, long term vision that has helped to shape a dynamic environment where tourism thrives, and their involvement in key business groups at a local and national level has ensured that Killarney's voice is at the forefront of Irish tourism. In Killarney, the influence of local entrepreneurs goes beyond provision of infrastructure and marketing, their approach to development has stimulated the actions of others, their strong lobbying, and the deliberate dependence of the larger businesses on smaller businesses for aspects of the tourism product allows Killarney tourism to thrive. Just as was acknowledged by Thomas et al's. (2011) they have been of great economic significance to the area through their collaboration and networking. These core entrepreneurs have, as suggested by Michael (2007), played an instrumental role in tourism development through their co-operative and complimentary interactions.

This study is an important addition to the research on the role of entrepreneurs in tourism development and reflects Hall (2004) and Tinsley \& Lynch's (2007) claim that entrepreneurs are key drivers of development. Their influence can be seen to transform areas into tourism destinations in the first instance (Koh \& Hatten, 2002) and has, as suggested Pearce (1992) extended to stimulate the involvement of others in tourism development. Their influence is long lasting and dynamic, in many cases spanning generations of involvement. Some entrepreneurs leave behind a legacy of development that is passed on for family members to continue. Others leave less tangible evidence of their influence, in these cases factors such as a strong vision and culture for tourism may influence 
tourism development for many, many years even when the original entrepreneur is no longer involved, and may have such a pervasive influence as to form part of the fabric of tourism development in the area.

It is clear that entrepreneurs play a pivotal role in tourism, and while the influence of the individual entrepreneur can be extensive and long lasting, a shared culture for tourism amongst entrepreneurs can result in a more pervasive influence on tourism development leading to the success of the area. This paper has provided a broad perspective on the influence of local entrepreneurs, acknowledging them as key 'tourism influentials' and as fundamental to tourism development. In essence, the research shows how the vision and influence of entrepreneurs can support a culture for tourism resulting in the creation of an environment where the focus for development is on the area in general and not just individual businesses. However, if a comprehensive understanding of entrepreneurial influence is to be achieved this area requires further investigation. In particular, research into the patterns of entrepreneurial activity and how these might differ between tourism places would add further important insight to the literature on entrepreneurs. 


\section{References}

Atkinson, O. (1956) The South and West of Ireland, Ireland and Me, New York, Random House.

Barrington, T.J. 1976: Discovering Kerry, its History, Heritage and Topography. Dublin, Blackwater Publications.

Britton, S. 1991: Tourism, capital and place: towards a critical geography of tourism. Environment and Planning D: Society and Space, 1991, Volume 9, $451-478$.

Butler, R.W. (1980): The Concept of a Tourist Area Cycle of Evolution: Implications for Management of Resources. Canadian Geographer, xxiv, 1, pp. 5 -m12.

Christaller, W. (1963): Some Considerations of Tourism Location in Europe: The Peripheral Regions - Underdeveloped Countries - Recreation Areas. Regional Science Association Papers 12, pp. 95 105.

Coles, T. 2006: Enigma Variations? The TALC, Marketing Models and the Descendents of the Product Life Cycle, in R. Butler (ed.) 2006: The Tourism Area Life Cycle Volume 2, Aspects of Tourism, Clevedon, England, Chanel View Publications, pp. 49-66.

Cork Examiner 1979.

Corr, F. 1924: Hotels in Ireland. Dublin, Jemma Publications.

Flynn, A. 1993: The Book of Kerry, Towns and Villages in the Kingdom. Wolfhound Press: Dublin. 
Gibson, L. \& Lynch, P. 2007: Networks: Comparing Community Experiences. in: Ewen, M.J. (ed.) 2007: Micro-Clusters and Networks: The Growth of Tourism. Elsevier, Oxford. pp. 107-126.

Gormsen, E. (1981): The spatio-temporal development of international tourism: attempt at a centreperiphery model, in La Consommation d'Espace par le Tourisme et sa Preservation, CHET, Aix-enProvence. Pp. 150-170

Hall \& Hall

Hall, C.M., 2004: Small Firms and Wine and Food Tourism in New Zealand: Issues of Collaboration, Clusters and Lifestyles. In Thomas, R., (ed.) 2004: Small Firms in Tourism, International Perspectives. Advances in Tourism Research Series, Elsevier Ltd., London

Hall, C.M. 2005: Rural wine and food tourism cluster and network development. In: D. Hall, I. Fitzpatrick, \& M. Mitchell (eds.) Rural Tourism and Sustainable business. pp. 149-164. Clevedon, Channelview.

Hall, C.M., Lynch, P. Michael, E.J. \& Mitchell, R. 2007: The Contribution of the Micro-Cluster Approach. in: Ewen, M.J. (ed.) 2007: Micro-Clusters and Networks: The Growth of Tourism. pp. 141-152 Elsevier, Oxford.

Horgan 
Horgan

Hovinen, G.R. (2002) Revisiting the Destination Life-Cycle Model, Annals of Tourism Research, Vol. 29, (1), pp. 209-30.

Johns, N \& Mattsson, J., 2005: Destination development through entrepreneurship: a comparison of two cases. Tourism Management, 26, pp 605-616.

Keen 2004

Keller, C.P. (1987): Stages of Peripheral Tourism Development - Canada's Northwest Territories, Tourism Management 8 (1), pp. 20-32

Killarney National Park, website accessed at: http://www.killarneynationalpark.ie/, January, 2008.

Koh, K.Y \& Hatten, T.S. 2002: The Tourism Entrepreneur: The Overlooked Player in Tourism Development Studies. International Journal of Hospitality \& Tourism Administration, Vol. 3(1).

Koh, K. 2002: Explaining a Community’s Touristscape: An Entrepreneurism Model. International Journal of Hospitality \& Tourism Administration. Vol. 3 (2), pp. 29-62.

Larner, J. (ed.) 2005: Killarney History and Heritage, Cork: The Collins Press.

Lewis, J.B., 1998: A Rural Tourism Development Model. Tourism Analysis, Volume 2, pp. 91-105.

Li, L. 2008: A review of entrepreneurship research published in the hospitality and tourism management journals. Tourism Management, Vol. 29, pp. 1013-1022.

Lundgren, J.O.J., 1982: The Tourist Frontier of Nouveau Quebec: functions and regional linkages, Tourist Review, 37 (2), pp. 10-16. 
MacLysaght, E. (ed.), 1970: The Kenmare Manuscripts. Irish University Press for the Irish Manuscripts Commission: Shannon.

McKercher, B., 1999: A chaos approach to tourism. Tourism Management, Volume 20, pp. 425-434.

Michael, E.J. 2007: Micro-Clusters in Tourism in: Ewen, M.J. (ed.) 2007: Micro-Clusters and Networks: The Growth of Tourism. Elsevier, Oxford. Pp. 33-42.

Miossec, J.M., 1976 : Elèments pour une Thèorie de l'Espace Touristique, Les Cahiers du Tourisme, CHET, Aix-en-Provence. Cited in: Pearce, D. (1995), Tourism Today, A Geographical Analysis, Second Edition, U.K., Longman Group Limited Mottiar, Z and Ryan, T. 2007: The role of SMEs in Tourism Development: An Industrial District Approach Applied to Killarney, Ireland in Thomas, R and Augustyn, M. Tourism in the New Europe: Perspectives on SME Policies and Practices, Elsevier: Amsterdam

Mottiar, Z. and Tucker, H. 2007: Webs of Power: Multiple Ownership in Tourism Destinations. Current Issues in Tourism Vol. 10, No. 4, pp. 279-295.

O'Hare, P., 2005: The Browne Family, Earls of Kenmare in J. Larner (ed) 2005: Killarney History and Heritage, Cork: The Collins Press, pp. 74-89.

Patton, M.Q., 2002: Qualitative Research \& Evaluation Methods $3^{\text {rd }}$ Edition. California: Sage. Pearce, D., 1995, Tourism Today, A Geographical Analysis, Second Edition, U.K., Longman Group Limited.

Ritchie, J.R.B, and Crouch, G.I. (2003): The Competitive Destination, A Sustainable Tourism Perspective. U.K., CABI Publishing. 
RPS Cairns Ltd. (1999) Killarney Visitor Survey [online] Available from: http://www.gttp.org/docs/casestudies/2000/ireland.pdf [Accessed: 22nd March 2004]

Russell, R., and Faulkner, B., 1999: Movers and Shakers: Chaos Makers in Tourism Development. Tourism Management, Volume 20, pp. 411-423.

Russell, R. (2006): The Contribution of Entrepreneurship Theory to the TALC model in: Butler, R.W., (ed.), (2006): The Tourism Area Life Cycle, Vol. 2, Conceptual and Theoretical Issues. Channel View Publications,U.K. pp.105-124.

Scott and Laws (2004)

Shapero, A. 1981: Entrepreneurship: Key to Self-Renewing Economies. Economic Development Commentary, Vol. 5 (2), pp. 19-23.

Shaw, G. \& Williams, A.M., 1998: Entrepreneurship and tourism development. In D. Ionnaides and K.G. Debbage (eds.) The Economic Geography of the Tourist Industry, pp. 235-255., London: Routledge.

Smith, C., 1756: The Ancient and Present State of the County of Kerry. The Mercier Press: Cork. The Kenmare Papers 1750-1850. Papers of the Browne Family, Earls of Kenmare. Public Record Office of Northern Ireland,

Thomas, R., Shaw, G., \& Page, S.J. 2011: Understanding small firms in tourism: A perspective on research trends and challenges. Tourism Management 32, pp. 963-976.

Tinsley, R. \& Lynch, P.A. 2001: Small tourism business networks and destination development. International Journal of Hospitality Management Volume 20 (4), pp. 367-378.

Tinsley, R. \& Lynch, P.A. 2007: Differentiation and tourism destination development: Small business success in a close-knit community. Tourism and Hospitality Research, Volume 8, (3), 16177. 
